\section{Eleutherodactylus juanariveroi (Puerto Rican Wetland Frog). Reproduction.}

Date of observation: 18 June 2007. Location: Puerto Rico: Sabana Seca; Toa Baja. Coordinates: 18.43466, -66.2047. Elevation: $2 \mathrm{~m}$. Voucher: video. This report documents vocalization behavior in male Eleutherodactylus juanariveroi. The frog was observed vocalizing from the frond of a fern (Thelypteris interrupta) in the swamp of Sabana Seca, approximately $0.8 \mathrm{~m}$ above the water. Another individual, a male very close to a clutch of eggs of this species, was attached to the interior leaf petiole of Sagittaria lancifolia in the fresh water marsh, just a few centimeters above the water surface. Other amphibian species calling were Eleutherodactylus coqui, E. cochranae and Leptodactylus albilabris. Thanks to Neftalí Ríos, and Alberto Estrada Puerta.

Alberto R. Estrada, Productions eleuth Inc., PMB 25635 JC de Borbon, Ste. 67, Guaynabo, Puerto Rico, 00969, peleuth@gmail.com.

Citation: Estrada AR. 2010. Eleutherodactylus juanariveroi (Puerto Rican Wetland Frog). Reproduction. Caribbean Herpetology 16:1.

Published online 13 December 2010 